\title{
ANALISIS YURIDIS TANGGUNG GUGAT KEGAGALAN PENGELOLA GUDANG OLEH LEMBAGA PELAKSANA PENJAMINAN SISTEM RESI GUDANG
}

\author{
Beta Madya Savitri \\ Fakultas Hukum, Universitas Airlangga \\ e-mail: beta.madya@gmail.com
}

\begin{abstract}
ABSTRAK
Resi gudang merupakan tanda bukti kepemilikan atas barang yang disimpan di gudang dan diterbitkan oleh Pengelola Gudang. Selain menerbitkan Resi Gudang, Pengelola Gudang memiliki kewajiban sebagaimana tercantum pada Perjanjian Pengelolaan Barang untuk menjaga barang yang dititipkan serta menyerahkan sesuai dengan keterangan yang tertera pada Resi Gudang. Adakalanya Pengelola Gudang melakukan wanpretasi yaitu tidak mampu memenuhi kewajibannya. Sekarang ini muncul Lembaga Pelaksana Penjaminan Sistem Resi Gudang yang selanjutnya disebut Lembaga Pelaksana. Lembaga Pelaksana adalah lembaga yang melaksanakan fungsi, tugas, kewajiban dan wewenang sebagai Lembaga Jaminan. Lembaga Pelaksana akan melindungi Hak Pemegang Resi Gudang dan/atau Penerima Hak Jaminan apabila terjadi kegagalan, ketidakmampuan, dan/atau kebangkrutan Pengelola Gudang dalam memenuhi kewajibannya. Lembaga Pelaksana juga berfungsi memelihara stabilitas dan integritas Sistem Resi Gudang sesuai dengan kewenangannya.
\end{abstract}

Kata kunci: jaminan; resi gudang; lembaga penjamin resi gudang

\begin{abstract}
Warehouse receipt is the evidence of goods ownership that is stored in a warehouse and issued by the warehouse superintendent. Besides issuing a warehouse receipt, the warehouse superintendent has obligation stated in the letter of goods management to maintain entrusted goods and to give them back based printed on warehouse receipt. There are time when warehouse superintendent is cannot fulfill their obligation. Now there are implementing institution quarantee collateral system of warehouse receipt called the implementing institution. The implementing institutition is institution which doing function, assigment, duty, and authority as a institution of quarantee. The implementing institutition will protect right of stakeholders and/or the guarantee receiver if there is a failure, incapacity and/or bankrupt by of the warehouse superintendent in carrying out their obligation. The implementing institutition also has function to mantain stability and integrity of warehouse receipt according their authority.
\end{abstract}

Keywords: guarantee; warehouse receipt; institution of collateral system of warehouse receipt

\section{PENDAHULUAN}

Permasalahan klasik pertanian di Indonesia adalah jatuhnya harga pada saat musim panen raya. Hal ini disebabkan karena para petani tidak dapat menyimpan hasil panen lebih lama dikarenakan sudah kehabisan biaya dan tidak memiliki gudang yang memadai. Kondisi ini dimanfaatkan para tengkulak dan rentenir untuk mengambil untung besar. Pemerintah berusaha menyelesaikan permasalahan tersebut salah satu caranya adalah dengan membentuk lembaga jaminan baru yaitu Hak Jaminan Resi Gudang. Pendeklarasian munculnya Hak Jaminan atas Resi Gudang ditegaskan pada penjelasan Pasal 12 ayat (1) Undang-Undang Nomor 9 Tahun 2006 tentang Sistem Resi Gudang sebagaimana diubah dengan Undang-Undang Nomor 9 Tahun 2011 
tentang Sistem Resi Gudang (selanjutnya disebut UU SRG).

Maksud pembentukan UU SRG adalah menciptakan sistem pembiayaan perdagangan yang diperlukan oleh dunia usaha, terutama usaha kecil dan menegah termasuk petani. Pada umumnya mereka menghadapi masalah pembiayaan karena keterbatasan akses ke perbankan dan tidak adanya jaminan kredit benda tidak bergerak. Selain itu juga adanya birokrasi dan administrasi yang berbelitbelit, kurangnya pengalaman bank dalam melayani wilayah pedesaan, tingginya biaya pinjaman dari sektor informal, tingginya tingkat risiko yang berhubungan dengan pengusaha atau produsen kecil, dan ketergantungan sektor formal terhadap pemerintah. ${ }^{1}$

Dengan adanya Hak Jaminan atas Resi Gudang, petani tidak harus tergesa-gesa untuk menjual hasil panennya, sebab para petani masih dapat menyimpan hasil panennya di gudang yang terakreditasi. Dalam pola Resi Gudang, petani menyimpan komiditi hasil panen ke Pengelola Gudang, selanjutnya petani mendapat bukti penyimpanan dalam bentuk Resi Gudang. Resi Gudang tersebut dapat dijadikan jaminan karena resi gudang termasuk surat berharga yang mewakili barang yang disimpan di gudang. Resi Gudang dapat dijadikan jaminan ke lembaga keuangan untuk mendapatkan talangan dana. Setelah berjalan beberapa waktu, yaitu pada masa penceklik atau harga di pasar cukup tinggi, maka hasil komoditi milik petani tersebut dapat dijual. Dari hasil penjualan tersebut petani dapat menebus dan mengembalikan pinjaman ke lembaga keuangan. Selanjutnya setelah dikurangi harga penjualan (harga pasar pada saat perjanjian resi gudang), akan terdapat selisih harga atau keuntungan. Keuntungan tersebut selanjutnya dibagi ke semua pihak yang terikat kontrak pola resi gudang dengan proporsi sesuai dengan kesepakatan.

Pada sistem resi gudang terdapat beberapa pihak yang terlibat antara lain Pihak-pihak yang telibat dalam Sistem Resi Gudang antara lain adalah Pemegang Resi Gudang, Pengelola Gudang, Badan Pengawas Sistem Resi Gudang, Lembaga Penilaian Kesesuaian, Pusat Registrasi, Lembaga

${ }^{1}$ Arief R. Permana dan Yulita Kuntari. (2006). "Selayang Pandang Undang-Undang Resi Gudang”. Buletin Hukum Perbankan dan Kebanksentralan, Vol. 4 No. 2 (mengutip Buku Informasi Sistem Resi Gudang sebagai Alternatif Pendanaan).
Jaminan Resi Gudang, dan Penerima Hak Jaminan. Hal yang menarik adalah Lembaga Jmainana Resi Gudang sebagaimana diatur pada pada Pasal 37 UU SRG. Lembaga Jaminan Resi Gudang (selanjutnya disebut Lembaga Pelaksana). Sebagai tindak lanjut ketentuan pasal tersebut, pemerintah menerbitkan Peraturan Pemerintah Nomor 1 Tahun 2016 tentang Lembaga Pelaksana Penjaminan Sistem Resi Gudang (selanjutnya disebut PP No. 1 Tahun 2016).

Dalam PP No. 1 Tahun 2016 tersebut, pemerintah menetapkan Perum Jaminan Kredit Indonesia (selanjutnya disebut Perum Jamkrindo) sebagai Lembaga Pelaksana Penjaminan Sistem Resi Gudang (selanjutnya disebut Lembaga Pelaksana). Lembaga Pelaksana adalah lembaga yang melaksanakan fungsi, tugas, kewajiban dan wewenang lembaga jaminan. Lembaga Pelaksana berfungsi hampir sama dengan Lembaga Penjamin Simpanan pada industri perbankan, bedanya jika Lembaga Penjaminan Simpanan menjamin uang masyarakat yang disimpan di bank, sedangkan Lembaga Pelaksana menjamin barang atau komoditi milik petani (masyarakat) yang disimpan oleh Pengelola Gudang. Fungsi Lembaga Pelaksana adalah melindungi hak pemegang resi gudang dan/atau penerima hak jaminan apabila terjadi kegagalan, ketidakmampuan, dan/atau kebangkrutan pengelola gudang dalam menjalankan kewajibannya. Selain itu juga berfungsi memelihara stabilitas dan integritas sistem resi gudang sesuai dengan kewenangannya.

\section{PERUMUSAN MASALAH}

Rumusan masalah dari penelitian ini antara lain adalah bagaimana karakteristik lembaga pelaksana sebagai lembaga jaminan resi gudang serta bagaimana kewenangan lembaga pelaksana terkait penyelesaian tanggung gugat kegagalan pengelola gudang akibat wanpestasi.

\section{METODE PENELITIAN}

Penelitian ini tergolong sebagai penelitian hukum untuk menemukan aturan hukum, prinsip-prinsip hukum, maupun doktrin-doktrin hukum dengan menggunakan hukum normatif dan melakukan telaah mengenai konsep-konsep hukum, serta pendapat para ahli hukum untuk meningkatkan daya interpretasi 
guna menjawab isu hukum yang dihadapi. ${ }^{2}$ Penelitian ini merupakan penelitian hukum karena ilmu hukum memiliki karakter yang khas (merupakan sui generis disipline) dan merupakan penelitian doctrinal (doctrinal research). Pendekatan masalah yang digunakan adalah pendekatan perundang-undangan (statute approach) yaitu pendekatan masalah dengan memperhatikan dan menganalisa perundangundangan yang berlaku khususnya undang-undang yang berhubungan dengan permasalahan di dalam penelitian ini. Pendekatan perundang-undang (statute approach), dilakukan dengan menelaah semua undang-undang dan regulasi yang bersangkut paut dengan isu hukum yang sedang dihadapi. ${ }^{3}$ Selain itu juga menggunakan pendekatan konseptual (conceptual approach) dengan beranjak dari pandangan-pandangan dan doktrin-doktrin sehingga akan ditemukan ide-ide yang melahirkan pengertianpengertian hukum, konsep-konsep hukum dan asas-asas hukum yang nantinya digunakan sebagai sandaran dalam membangun suatu argumentasi.

Dalam penelitian ini, menggunakan analisis normatif kualitatif yaitu cara memperoleh gambaran singkat suatu masalah yang didasarkan atas suatu peraturan perundang-undangan yang berlaku dan berkaitan dengan permasalahan yang dibahas, serta menggunakan metode analisis bahan hukum deduktif, yaitu suatu metode penelitian berdasarkan konsep atau teori yang bersifat umum diaplikasikan untuk menjelaskan tentang seperangkat fakta hukum yang ada kemudian diteliti serta dianalisis dengan bahan hukum yang diperoleh, ditambahkan dengan pendapat para sarjana yang berhubungan dengan masalah hukum yang ada, untuk dapat ditarik kesimpulan.

\section{PEMBAHASAN}

\section{Karakteristik Lembaga Pelaksana Dalam Jaminan Resi Gudang}

Pembentukan Lembaga Pelaksana dalam sistem resi gudang merupakan amanat dari UU SRG dan PP No. 1 Tahun 2016. Dalam aturan tersebut mengatur tentang adanya kelembagaan baru terkait penjaminan lembaga resi gudang, yaitu adanya Lembaga Jaminan Resi Gudang adalah badan hukum Indonesia yang

\footnotetext{
2 Peter Mahmud Marzuki. (2005). Penelitian Hukum. Jakarta: Kencana Prenada Media Group, h. 35.

3 ibid., h. 133.
}

menjamin hak dan kepentingan Pemegang Resi Gudang dan Penerima Hak Jaminan terhadap kegagalan, kelalaian, atau ketidakmampuan Pengelola Gudang dalam melaksananakan kewajibannya dalam menyimpan dan menyerahkan barang. Fungsi Lembaga Jaminan Resi Gudang dilaksanakan oleh Lembaga Pelaksana.

Pada Peraturan Pemerintah Nomor 10 Tahun 2014 tentang Persyaratan dan Tata Cara Penetapan Lembaga Pelaksana Penjaminan Sistem Resi Gudang (selanjutnya disebut PP No. 10 Tahun 2014), pada Pasal 3 mengatur bahwa Lembaga Pelaksana harus memenuhin persyaratan:

a. lembaga atau badan usaha yang seluruh atas sebagian modalnya dimiliki oleh negara;

b. mempunyai pengalaman paling sedikit 3 (tiga) tahun di bidang penjaminan;

c. kegiatan dari lembaga atau badan usaha tersebut terkait dengan kegiatan Sitem Resi Gudang;

d. memiliki sistem dan sarana yang terkait dengan penjaminan atau Sistem Resi Gudang; dan

e. memiliki komitmen untuk mengutamakan pengembangan dan keamanan Sistem Resi Gudang.

Pemerintah dalam hal ini menujuk Perum Jamkrindo sebagai Lembaga Pelaksana. Lembaga Pelaksana adalah lembaga yang menjalankan fungsi, tugas, kewajiban, dan wewenang Lembaga Jaminan dalam sistem resi gudang. Dengan demikian, maka Perum Jamkrindo akan bertugas mengelola dana jaminan yang melindungi pemilik barang maupun lembaga pembiayaan dari risiko yang dapat terjadi akibat wanprestasi atau ketidakmampuan Pengelola Gudang menjalankan kewajiban dan tanggung jawabnya dalam menjaga kualitas dan kuantitas barang sebagaimana tertera pada Resi Gudang.

Lembaga Pelaksana memiliki fungsi melindungi hak Pemegang Resi Gudang dan/atau Penerima Hak Jaminan, apabila terjadi kegagalan, ketiakmampuan, dan/atau kebangkrutan Pengelola Gudang dalam menjalankan kewajibannya. Disamping itu lembaga ini akan memelihara stabilitas dan integritas Sistem Resi Gudang sesuai dengan kewenangannya. Dengan adanya Lembaga Pelaksana, petani dan para pelaku usaha lainnya menjadi lebih yakin dan merasa aman untuk memanfaatkan Sistem Resi Gudang, lembaga keuangan tidak lagi ragu dalam memberikan pembiayaan Sistem Resi Gudang sehingga dapat 
menggerakkan roda perekonomian di daerah yang akan berdampak secara nasional.

Kedudukan Lembaga Pelaksana adalah sebagai penanggung dengan didasarkan atas dibayarnya premi oleh Pengelola Gudang, namun premi yang dibayar ini berbeda dengan konsep premi pada asuransi. Premi pada asuransi ditetapkan dengan memperhatikan segala kondisi dari tertanggung, sedangkan premi yang diterima oleh Lembaga Pelaksana berupa premi penjaminan yang ditetapkan berdasarkan jumlah dan jenis barang yang disimpan oleh Pengelola Gudang. Premi penjaminan yang dibayar oleh Pengelola Gudang ini akan digunakan sebagai dana pembayaran klaim apabila Pengelola Gudang mengalami kegagalan atau kebangkrutan sehingga tidak dapat memenuhi kewajibannya dan klaim akan dibayarkan kepada pihak yang dirugikan. Berikut konsep secara rinci terkait pengajuan klaim atas pelaksaan jaminan oleh Lembaga Pelaksana dalam Sistem Resi Gudang:

\section{Bagan Pengajuan Klaim Jaminan Kepada Lembaga Pelaksana}

$\begin{aligned} & \text { 1. Pemegang Resi Gudang dan/atau Penerima Hak Jaminan } \\ & \text { mengajukan klaim kepada Lembaga Pelaksana }\end{aligned}$
$\begin{aligned} & \text { 2. Lembaga Pelaksana melakukan verifikasi dengan cara } \\ & \text { meminta data dan informasi kepada Pengelola Gudang dan } \\ & \text { Pusat registrasi }\end{aligned}$
$\begin{aligned} & \text { 3. Lembaga Pelaksana melakukan verifikasi dengan cara } \\ & \text { berkoordinasi dengan Badan Pengawas Resi Gudang } \\ & \text { berupa menerima atau menolak klaim dalam jangka waktu } \\ & \text { paling lama 14 hari sejak klaim diajukan }\end{aligned}$
5. Dalam hal klaim memenuhi persyaratan untuk diterima,
Lembaga Pelaksana membayarkan klaim kepada Pemegang
Resi Gudang dan/atau Penerima Hak Jaminan paling lambat
30 hari kerja sejak klaim diterima

\section{Penjelasan:}

1. Pemegang resi gudang dan/atau penerima hak jaminan mengajukan klaim kepada lembaga pelaksana.

2. Lembaga pelaksana melakukan verifikasi serta meminta data dan informasi yang dibutuhkan kepada pengelola gudang dan juga pusat regitrasi.
3. Dalam melakukan verifikasi lembaga pelaksana berkoordinasi dengan badan pengawas resi gudang.

4. Lembaga pelaksana melakukan peninjauan dan mmberikan hasil verifikasi berupa keputusan menolak atau menerima klaim dalam waktu 14 hari kerja sejak klaim diajukan.

5. Dalam hal pengajuan klaim memenuhi persyaratan untuk diterima, lembaga pelaksana membayarkan kalim kepada pemegang resi gudang dan/atau penerima hak jaminan. Apabila dokumen resi gudang memiliki hak tagih utama (kreditur preferen) adalah penerima hak jaminan sehingga lembaga pelaksana mendahulukan penggantian kerugian kepada penerima hak jaminan daripada pemegang resi gudang. Namun jika resi gudang tidak dibebankan jaminan, maka hak tagih utama tetap kepada pemegang resi gudang.

Pada Pasal 14 PP No. 1 Tahun 2016 mengatur bahwa setiap Pengelola Gudang yang melakukan kegiatan usaha di wilayah Republik Indonesia wajib menjadi peserta penjaminan yang dilaksanakan Lembaga Pelaksana. Lebih lanjut pada Pasal 15 mengatur mengenai kewajiban peserta penjaminan antara lain menyerahkan surat pernyataan, membayar premi penjaminan atas setiap barang yang disimpan, menyerahkan laporan berkala sesuai dengan format yang telah ditentukan oleh Lembaga Pelaksana, memberikan data, informasi, dan dokumen-dokumen yang diperlukan atau diminta oleh Lembaga Pelaksana dan menempatkan bukti kepesertaan atau salinannya di dalam kantor Pengelola Gudang dan tempat lain yang mudah diketahui oleh masyarakat.

\section{Kewenangan Lembaga Pelaksana Terkait Penyelesaian Tanggung Gugat Kegagalan Pengelola Gudang Akibat Wanprestasi}

\section{Dasar kontraktual dalam penjaminan resi gudang oleh Lembaga Pelaksana}

Dalam pelaksanaan penjaminan pada sistem resi gudang didasarkan pada 2 (dua) perjanjian dan masing-masing terdapat hubungan kontraktual. Perjanjian adalah suatu peristiwa dimana seorang berjanji untuk melaksanakan sesuatu hal. ${ }^{4}$ Perjanjian yang pertama adalah berupa kesepakatan yang terjadi antara Pengelola Gudang dengan Lembaga Pelaksana. Lembaga Pelaksana melakukan Perjanjian Pengelolaan karena terdapat hak pengelolaan apabila Pengelola Gudang dinyatakan pailit dan juga adanya kesepakatan terkait pengelolaan dana premi yang dibayar oleh Pengelola Gudang. Sedangkan perjanjian

\footnotetext{
${ }^{4}$ Djaja S. Meliala. (2007). Perkembangan Hukum Perdata tentang Benda dan Perikatan. Bandung: Nunasa Aulia, h. 78.
} 
yang kedua terjadi antara Pengelola Gudang dengan Pemilik Barang sebagaimana tercantum pada Surat Perjanjian Pengelolaan Barang. Surat Perjanjian Pengelolaan Barang dalam resi gudang termasuk dalam Perjanjian Penitipan Barang. Dimana Pemilik Barang menitipkan barang komoditinya kepada Pengelola Gudang untuk dijaga dan dirawat dengan baik selama penyimpanan.

Perjanjian Pengelolaan Barang (dalam UU Resi Gudang menggunakan istilah Surat Perjanjian Pengelolaan Barang) adalah surat perjanjian yang ditandatangani oleh Pengelola Gudang dengan pihak pemilik barang tentang penyimpanan barang yang sekurang-kurangnya memuat: a. identitas para pihak; b. hak dan kewajiban para pihak; c. jangka waktu penjaminan; d. uraian/deskripsi barang; e. biaya penyimpanan; f. biaya asuransi; g. cara penagihan; h. klaim ganti rugi; i. penyelesaian sengketa/ perselisihan; j. penutup.

\section{Gugat Berdasarkan Wanprestasi Oleh Pengelola Gudang dan Peran Lembaga Pelaksana Sebagai Lembaga Jaminan Resi Gudang}

Wanprestasi menurut J. Satrio adalah suatu peristiwa atau keadaan, dimana debitur tidak telah memenuhi kewajiban prestasi perikatannya dengan baik, dan debitur punya unsur salah atas tidak dipenuhinya kewajiban perikatan itu. Maksud unsur salah adalah adanya unsur salah pada debitur atas tidak dipenuhinya kewajiban itu sebagaimana mestinya. ${ }^{5}$ Sedangkan wanprestasi menurut Abdulkadir Muhammad artinya tidak memenuhi kewajiban yang telah ditetapkan dalam perikatan. ${ }^{6}$

Pengelola Gudang dalam Sistem Resi Gudang dikatakan melakukan wanprestasi apabila tidak memenuhi kewajiban prestasi sebagaimana telah diatur dalam perjanjian. Prestasi yang dimaksud disini adalah kewajiban untuk memberikan atau menyerahkan sesuatu. Sesuatu yaitu barang yang disimpan di gudang. Sedangkan perjanjian yang dimaksud adalah berdasarkan perjanjian pengelolaan antara Pengelola Gudang dengan Lembaga Pelaksana.

\footnotetext{
${ }^{5}$ J. Satrio. (2012). Wanprestasi Menurut KUHP Perdata, Doktrin, dan Yurispudensi. Bandung: Citra Aditya Bakti, h.18.

${ }^{6}$ Abdulkadir Muhammad. (2001). Hukum Perikatan. Bandung: Citra Adityabakti, h. 20.
}

Terhadap wanprestasi berupa kegagalan, ketidakmampuan, kelalaian, dan kebangkrutan Pengelola Gudang yang merugikan pihak lain, dapat diajukan tanggung gugat. Namun sejak adanya PP No. 1 Tahun 2016 segala tanggung jawab Pengelola Gudang dalam Sistem Resi Gudang tersebut dialihkan kepada Lembaga Pelaksana.

Lembaga Pelaksana dalam hal ini Perum Jamkrindo akan menerima dana premi yang wajib dibayarkan oleh Pengelola Gudang sebagai peserta penjaminan. Premi tersebut berfungsi sebagai dana jaminan dan akan melindungi hak Pemegang Resi Gudang dan/atau Penerima Hak Jaminan. Dana Jaminan Resi Gudang (Idemnity Fund) inilah yang akan berfungsi sebagai penjamin apabila terdapat Pengelola Gudang yang mengalami kebangkrutan. Dalam hal Resi Gudang dibebankan Hak Jaminan maka penggantian kerugian oleh Lembaga Pelaksana akan mendahulukan kepada Penerima Hak Jaminan daripada Pemegang Resi Gudang.

Lembaga Pelaksana hanya menganti kerugian yang mungkin diderita oleh Pemegang Resi Gudang dan atau Penerima Hak Jaminan atas wanprestasi yang dilakukan oleh Pengelola Gudang. Lembaga Pelaksana tidak menjamin kerugian yang disebabkan oleh keadaan memaksa (overmacht/force majeur). Hal ini sesuai dengan ketentuan Pada Pasal 17 ayat (2) PP No. 1 Tahun 2016 dijelaskan bahwa Lembaga Pelaksana tidak menjamin kerugian apapun yang disebabkan oleh keadaan kahar. Maka dalam hal ini jelas bahwa tangung gugat kepada Lembaga Pelaksana hanya terbatas wanprestasi nya Pengelola Gudang dalam memenuhi kewajibannya dan tidak dapat diajukan atas dasar overmacht/forcemajeur.

Dalam menangani Pengeloala Gudang gagal, Lembaga Pelaksana juga dapat bertindak sebagaimana diatur dalam Pasal 6 ayat (3) PP No. 1 Tahun 2016 menyatakan bahwa "dalam melakukan penyelesaian dan penanganan Pengelola Gudang gagal, Lembaga Pelaksana dapat bertindak sebagai kreditur terhadap Pengelola Gudang berdasarkan hak subrogasi dari Pemegang Resi Gudang dan/atau Penerima Hak Jaminan yang dapat mengajukan permohonan pailit kepada Pengadilan Niaga".

Pada penjelasan Pasal 6 dijelaskan bahwa yang dimaksud dengan "hak subrogasi" adalah penggantian pemegang hak tagih dari Pemegang Resi Gudang dan/atau Penerima Hak Jaminan kepada Lembaga 
Pelaksana, setelah Pemegang Resi Gudang dan/atau Penerima Hak Jaminan menerima pembayaran klaim dari Lembaga Pelaksana.

\section{PENUTUP}

\section{Kesimpulan}

Pada sistem resi gudang terdapat beberapa lembaga yang saling terkait. Lembaga yang paling baru muncul adalah Lembaga Pelaksana. Lembaga Pelaksana adalah lembaga yang melaksanakan fungsi, tugas, kewajiban dan wewenang lembaga jaminan. Lembaga Pelaksana berfungsi hampir sama dengan Lembaga Penjamin Simpanan (selanjutnya disebut LPS) pada industri perbankan, bedanya jika LPS menjamin uang masyarakat yang disimpan di bank, sedangkan Lembaga Pelaksana menjamin barang atau komoditi milik petani (masyarakat) yang disimpan oleh pengelola gudang. Fungsi Lembaga Pelaksana adalah melindungi hak pemegang resi gudang dan/ atau penerima hak jaminan apabila terjadi kegagalan, ketidakmampuan, dan/atau kebangkrutan pengelola gudang dalam dalam menjalankan kewajibannya. Selain itu juga berfungsi memelihara stabilitas dan integritas sistem resi gudang sesuai dengan kewenangannya. Namun kewajiban penggantian oleh Lembaga Pelaksana hanya terbatas pada wanprestasi yang dilakukan oleh Pengelola Gudang tidak dibebankan pada keadaan kahar/keadaan memaksa.

\section{Rekomendasi}

Tanggung gugat dan penanganan atas kegagalan pengelola gudang yang diambil alih oleh lembaga pelaksana, hendaknya dijelaskan secara rinci mengenai makna Pengelola Gudang gagal yang berdampak luas (sistemik) dan tidak berdampak luas, karena keberadaan Lembaga Pelaksana ini sangat berkaitan dengan kepercayaan pelaku usaha dari skala kecil sampai skala besar. Termasuk juga harus diatur peraturan tersendiri terkait penanganan Pengelola Gudang gagal yang nantinya diharapkan tidak bersinggungan dengan peraturan perundangundangan lain, seperti Undang-Undang Pasar Modal.

\section{DAFTAR PUSTAKA}

\section{Peraturan Perundang-undangan :}

Undang-Undang Nomor 9 Tahun 2011 Tentang Sistem Resi Gudang.

Peraturan Pemerintah Nomor 1 Tahun 2016 tentang Lembaga Pelaksana Penjaminan Sistem Resi Gudang.

Peraturan Pemerintah Nomor 10 Tahun 2014 tentang Persyaratan dan Tata Cara Penetapan Lembaga Pelaksana Penjaminan Sistem Resi Gudang.

\section{Buku:}

Abdulkadir Muhammad. (2001). Hukum Perikatan. Bandung: Citra Adityabakti.

Djaja S. Meliala. (2007). Perkembangan Hukum Perdata tentang Benda dan Perikatan. Bandung: Nunasa Aulia.

J. Satrio. (2012). Wanprestasi Menurut KUHP Perdata, Doktrin, dan Yurispudensi. Bandung: Citra Aditya Bakti.

Peter Mahmud Marzuki. (2005). Penelitian Hukum. Jakarta: Kencana Prenada Media Group.

\section{Sumber Lain:}

Arief R. Permana dan Yulita Kuntari. (2006). "Selayang Pandang Undang-Undang Resi Gudang”. Buletin Hukum Perbankan dan Kebanksentralan, Vol. 4 No. 2 (mengutip Buku Informasi Sistem Resi Gudang sebagai Alternatif Pendanaan). 